\title{
A TRAGÉDIA GREGA E SEU CONTEXTO*
}

\author{
Jorge Ferro Piqué**
}

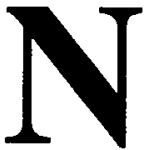

ormalmente encaramos uma tragédia grega como um livro sobre o qual nos debruçamos intelectualmente com o objetivo de extrair alguma compreensão sobre como os gregos sentiam o trágico em suas vidas e como o expresssavam artisticamente.

Essa tem sido a principal abordagem ao longo desses últimos séculos e foi dessa maneira que a civilização ocidental incorporou e transformou essa forma artística única criada pelos gregos.

No entanto, é claro que não era assim para os próprios gregos. Justamente no século $\mathrm{V}$ a.C., o momento de maior relevo do teatro ático, é que começamos a perceber o surgimento de uma cultura verdadeiramente letrada na Grécia antiga, com a elaboração e venda de livros, mas este importante fenômeno se dá ainda de forma incipiente. Mantém-se na verdade uma permanente tensão entre o oral e o escrito e que pode ser sentida mesmo no século seguinte na obra de Platão, em que a escrita é apresentada com certa desconfiança.

* Este artigo foi baseado na conferência "Tragédia grega: ambiente e formas" apresentada no Curso de Extensão Universitária “A arte trágica", realizada em 15 de setembro de 1997. A versão integral em hipertexto com imagens ilustrativas pode ser encontrada em http://www.humanas.ufpr.br/defi/tragedia/pique.htm

** Universidade Federal do Paraná (e-mail: jorge@humanas.ufpr.br, URL: www.humanas.ufpr.br/delin/classic/jpique.htm) 
Aos poucos, entretanto, a experiência da leitura de tragédias se consolida e é célebre a passagem em que Aristóteles declara que é possível alcançar também o efeito trágico ao apenas ler uma peça, sem uma performance pública. Embora pudéssemos dizer que deveria ser certamente mais prazeroso apenas ler tragédias de Ésquilo, Sófocles e Eurípides do que ir ao teatro para assistir às peças que eram encenadas no século IV a.C., à época de Aristóteles, nenhuma das quais chegou até nós, certamente por suas poucas qualidades artísticas.

Hoje, para nós, a possibilidade mais comum de contato com as tragédias gregas é através de sua transcrição em um livro e em geral em tradução para as línguas européias modernas. Infelizmente no Brasil ainda não temos a nossa disposição montagens regulares e sistemáticas do teatro grego que poderiam sem dúvida abrir novas possibilidades de encontro com o trágico assim como era percebido pelos gregos. ${ }^{1}$

Mas, apesar dessas poucas montagens esparsas, o que vemos em cena ainda está muito distante do fenômeno trágico como era experimentado em Atenas no século V a.C.

Será portanto o objetivo deste artigo fornecer alguns dados obtidos pelas investigações recentes sobre o ambiente geral da performance teatral trágica, ambiente em seu sentido mais amplo, isto é, sua inserção social e cultural e suas condições materiais de existência, e que em geral não estão acessíveis de forma imediata a um leitor ou mesmo espectador contemporâneo, de modo a termos uma visão mais ampla sobre este tema e podermos, a partir daí, ir adiante no questionamento propriamente do conteúdo trágico, o que pretendemos fazer em um próximo artigo.

\section{Os festivais dionisíacos}

O ambiente mais geral onde se insere o teatro trágico ático é o da comunidade, especificamente o da cidade, e o da religião, na forma social de sua expressão.

A religião grega pode ser abordada por dois aspectos mais exteriores. De um lado, o lugar sagrado, onde o contato com os deuses se realiza através de sacrifícios, de outro, a festa, quando em determinados dias do ano, aos quais é acrescentada a noite anterior, se dá uma quebra do ritmo cotidiano. Assim, se o templo acentua o espaço da comunidade, a festa acentua a sua temporalidade.

1 No caso das comédias gregas a situação é ainda pior, sendo um acontecimento raro a sua encenação no palco. 
Era nas festas, heortaí, que a religião viva, verdadeiramente praticada, se concentrava. Durante as festividades religiosas o trabalho específico, seja produtivo ou não, cessa, a distribuição social de papéis torna-se mais frouxa e há um clima de descontração generalizado. Mas não só isso. Novos papéis são criados momentaneamente, novos grupos se associam e separam-se. É um momento especial e que de diferentes formas é destacado do cotidiano. Segundo Burkert ${ }^{2}$ " [....] o contraste em relação ao habitual pode exprimir-se no prazer $\mathrm{e}$ na alegria, nos adornos e na beleza, mas também na ameaça e na morte".

A tragédia grega era na verdade parte de uma das principais festividades religiosas anuais que se realizavam em Atenas, as Grandes Dionísias Urbanas.

Atenas, como as demais cidades gregas, tinha o seu calendário anual recortado por inúmeras e diferentes festas. Na verdade cada cidade grega tinha a sua sucessão particular de festivais religiosos e portanto o seu próprio calendário. Mais ainda, havia festas exclusivas apenas de determinada tribo dentro de uma cidade. Seu número era muito grande, e o calendário melhor conhecido por nós é o ático. Em Atenas, presumimos que seriam por volta de 60 dias dedicados exclusivamente a festividades religiosas durante $o$ ano. Portanto, poderíamos dizer que se vive "normalmente" de uma festa até a outra. Estas são tão significativas que em geral os próprios nomes dos meses ligam-se às festividades mais importantes realizadas naquele período de tempo. No mês Anthesterión, por exemplo, se realizava a festa das Antestérias, a festa das flores e do vinho novo, no início da primavera.

A festa na qual eram apresentadas as tragédias gregas era em homenagem ao deus Dioniso.

Dioniso era um deus ligado a diversas festividades. Na Ática, que nos interessa mais de perto, havia os seguintes tipos de festivais dionisíacos ${ }^{3}$ :

- as Lenéias: as festas dos tonéis de vinho, aproximadamente em janeiro;

- as Antestérias: o mais antigo dos festivais dionisíacos e por isso também chamados de "Velhas Dionísias", aproximadamente em fevereiro, quando os barris eram abertos e se experimentava o vinho novo;

- as Oscofórias: o festival da colheita das uvas, realizado aproximadamente em outubro, quando havia uma corrida de rapazes levando ramos de parreiras.

2 BURKERT, W. Religião grega na época clássica e ancaica. Lisboa: Fundaçāo Calouste Gulbenkian, 1993. p. 207.

3 Ibid., p. 318-322; HARVEY, P. Dicionário Oxford de literatura clássica. Rio de Janeiro: J. Zahar, 1987. p. 231. 
Para nós, é mais importante um determinado conjunto de festividades em honra a Dioniso, as Dionísias, que se dividiam em urbanas e rurais, e especificamente a primeira delas.

As Dionísias Urbanas ocorriam em dois momentos no calendário. Primeiramente na primavera, logo após as Antestérias, em fins de março, quando o vinho do último ano estava maduro, pronto para beber, fazendo-se portanto a abertura dos barris. O sentimento geral era de que a terra estava acordando para uma nova vida, indicando uma continuidade da temática do "florescimento" que marcava esse mês. Mas havia também uma Dionísia Urbana no inverno, para marcar o fim do trabalho anual e que, em Atenas, ocorria no início de janeiro.

Já as Dionísias Rurais eram de menor proporção e aconteciam em dezembro, inverno portanto, nos distritos rurais da Ática. Nelas, um kômos, isto é, um bando de foliões, carregando um falo de grandes proporções, cantava canções para Dioniso, as chamadas "canções fálicas". Nos intervalos, o líder divertia os espectadores com vulgaridades, na forma de monólogo ou diálogo. Muitos autores consideram que foi justamente o kômos uma das origens do coro, um dos aspectos mais particulares do drama grego, tanto na tragédia como na comédia.

As Dionísias Urbanas ou Grandes Dionísias tinham a seguinte forma. ${ }^{4}$ Iniciavam-se por uma procissão que escoltava uma antiga imagem de Dioniso ao longo da estrada que conduzia à cidade de Eleutéria e regressava depois ao altar do deus, em Atenas, onde um bode era sacrificado em meio a danças e canções. Uma virgem conduzia a procissão através do caminho, adornada com ornamentos dourados, portando a cesta sagrada, cheia de bolos e flores. Os outros participantes da procissão conduziam presentes rurais (uvas, figos, vinho etc.) e o animal a ser sacrificado. Um falo era carregado no alto.

Neste cortejo ritual $^{5}$ já podemos perceber a forma fundamental da constituição de grupos. Da massa amorfa são destacados os participantes ativos que se dirigem para um objetivo, mas a interação com o outro grupo que se forma simultaneamente ao longo do caminho, ou seja, os espectadores, é tão importante quanto o próprio objetivo pelo qual se forma o cortejo. O objetivo da pompé é naturalmente um santuário no qual terá lugar o sacrifício, mas o próprio caminho também tem significado, é "sagrado". Em algumas outras procissões religiosas são apresentadas já dramatizações de caráter mimético da partida, o abandono do santuário, prefigurando no ritual a futura forma dramática. p. 167-170.

4 AMOURETTI, M. C.; RUZÉ, F. O mundo grego antigo. Lisboa: Dom Quixote, 1993.

5 Cf. gr. pompé. Existe o termo equivalente latino pompa, com o mesmo significado. 
Dentro do grupo dos participantes ativos, por sua vez, existem papéis bem definidos, como a portadora do cesto, ou os portadores do falo, no caso das Grandes Dionísias. Em outras procissões temos a portadora da água, o portador do fogo, das taças etc. Os participantes indicam o seu estatuto particular não apenas pelo vestuário festivo, mas também pelas coroas, faixas de lã e pelos ramos que levam nas mãos. Esse uso de sinais exteriores dos papéis a serem exercidos no ritual será sem dúvida apropriado mais tarde pelo teatro. ${ }^{6}$

Torna-se claro então como as procissões, hinos e danças de caráter festivo-religioso prefiguravam de certo modo as formas que o teatro grego mais tarde assumiria. O divertido kômos e a solene pompé são a contrapartida puramente ritual dos coros cômicos e trágicos do teatro grego.

Observemos também uma outra semelhança entre o ritual de Dioniso e a tragédia. A forma como o festival dionisíaco acontecia na Ática era bem diferente de suas manifestações orientais, nas quais era observada violência selvagem e extática, além de serem realizadas no inverno e à noite. Ocorreu portanto já no nível do ritual a passagem de uma simplicidade rude e às vezes brutal à graça, dignidade e refinamento que serão também características da tragédia ática.

Vejamos agora algo sobre o próprio deus homenageado nas Grandes Dionísias. ${ }^{7}$ Dioniso é um deus que está associado ao fruto carnudo e suculento, como a uva ou o figo. Nesse sentido se opõe a Deméter, deusa dos cereais, do trigo, da cevada. Se por um lado a fruta nos dá essa sensação de prazer imediato, o grão é pouco saboroso, mas os dois tipos de alimentos se completam, pois é o grão que sustenta, é ele que simboliza a civilização, o plantio e portanto o esforço humano. ${ }^{8} \mathrm{O}$ fruto carnudo e doce, ao contrário, é coletado diretamente e portanto é uma dádiva da natureza. Dioniso é então esse deus do contato direto, sem esforço, com o prazer.

No entanto, a oposição e complementação mais conhecida é entre Apolo e Dioniso. Embora Apolo nos poemas homéricos tenha também um caráter violento (são suas flechas que na Ilíada dizimam os aqueus a pedido de seu sacerdote Crises ${ }^{9}$ ), por estar associado à música e à poesia através da lira (que na verdade revela a violência original do arco e da flecha), Apolo acabou

6 O monumento clássico que permite uma visualização completa de uma grande pompé é o friso das Panatenéias no Partenon.

7 ELIADE, M. História das crenças e das idéias religiosas. Tomo I, v. 1-2. Rio de Janeiro: J. Zahar, 1978. p. 202.

8 Já Homero identificava os grupos humanos civilizados por serem "comedores de pão".

9 HOMĖRE. Iliade. Paris: Les Belles Lettres, 1936, I, v. 30-45. 
tornando-se o deus por excelência da simetria da forma, da grave determinação, da seriedade de tom, características que hoje chamamos apolíneas. ${ }^{10}$

Dioniso parece ser uma outra vertente de um mesmo princípio. Também está associado à poesia e à música como Apolo, mas seu instrumento é a "flauta". Aqui cabe uma pequena observação esclarecedora. $O$ termo grego que em geral é traduzido por "flauta" é aulós. Este instrumento duplo de sopro provavelmente teria um som mais próximo ao oboé ou à gaita de foles escocesa, nada relacionado portanto à sonoridade suave das nossas flautas atuais e mais apropriado aos êxtases dionisíacos.

Desde cedo Dioniso foi associado à idéia de irregularidade, seja no ritmo ou na linguagem, a princípio, e, conseqüentemente, nos próprios sentimentos. Essa ciclotimia se reflete bem na falta de restrições que encontramos na poesia coral dionisíaca executada nos sacrifícios ofertados nas festas a esse deus. Em geral assumiam a forma de um hino em celebração das dádivas de Dioniso. Nesse hino a música era executada no modo frígio, reforçando um dos mitos de uma origem não-grega do deus, que teria vindo da Frígia. Hoje, no entanto, sabemos que o culto de Dioniso é muito antigo na Grécia, remontando à época micênica. ${ }^{11}$

$O$ verso utilizado era o ditirambo e o hino assumia a forma de uma dança coral acompanhada de gestos e movimentos ilustrativos. Essa dança mimética denominava-se órchesis.

As características especiais de Dioniso acabaram por atrair outros seres a princípio de origem heterogênea, tais como os sátiros, possuidores de características animalescas e que representariam forças vigorosas da natureza, paixões e emoções da mente humana. Em geral são representados como covardes, sensuais, livres e bem-humorados e com um pênis em permanente ereção. Havia também os Silenos, sátiros velhos, bêbados e lascivos. Já as Bacantes ou Mênades eram entidades femininas, às vezes ninfas, às vezes mulheres mortais, que tomavam parte no cortejo de Dioniso com os cabelos soltos e enfeites florais e cuja forma de contato com a divindade era o êxtase, o entusiasmo. Vemos igualmente associados a Dioniso os Centauros, representantes também da força e do vigor natural e amantes da embriaguês e finalmente Pan, deus da vida rural.

Esse conjunto de seres configuraria na imaginação grega algo que é recorrente em várias culturas de diferentes formas, ou seja, esse sentimento de que há algo pulsante e incontrolável no mundo, mas que é também uma manifestação de uma dimensão superior ao homem, algo que se por um lado

10 ELIADE, op. cit., p. 257.

11 Na antiga Grécia havia outros centros de culto dionisíaco além de Atenas, tais como Tebas, Corinto e Naxos. 
pode ser fonte de alegria e libertação, por outro pode ser também perigoso e mesmo mortal. Algo por fim que representa um mistério.

Importante detalhe para nós nos cultos a Dioniso é o uso da máscara por seus seguidores. Dioniso, na sua relação com os homens, quer mais do que oração e sacrifício, quer a pessoa inteira ao seu serviço, e por meio do êxtase a eleva acima de todas as misérias do mundo. A máscara representa o elemento de transformação, de perda de identidade e é nela por seu turno que se baseia também a essência da representação dramática, dando ao teatro grego uma peculiaridade não encontrada nos demais gêneros e que foi mantida até os dias de hoje.

Será justamente nesse ambiente religioso e festivo que será introduzido a posteriori o teatro.

Isso ocorreu em Atenas no século VI a. C. sob a tirania de Pisístrato. Cabe aqui uma pequena explicação histórica. $O$ regime tirânico foi ao mesmo tempo uma emanação da aristocracia e uma reação contra ela. $O$ poder estava nas mãos de famílias célebres que o administravam ou através de um regime monárquico ou de um regime oligárquico. $O$ poder podia ser transmitido ou hereditariamente ou de forma eletiva, mas sempre estava nas mãos da aristocracia. Com o surgimento de uma série de crises no seio da aristocracia ocorriam casos em que um aristocrata tomava o poder indevidamente, apoiado por outros aristocratas e/ou por um grupo de cidadãos. Pisístrato foi um desses tiranos "populares". Na verdade tomou e perdeu o poder três vezes na segunda metade do século VI a.C. ${ }^{12}$ Foi justamente durante o último período de tirania que Pisístrato, preocupado com o apoio popular, estabeleceu a regulamentação das representações teatrais em Atenas.

Antes disso o teatro tinha um caráter privado e voluntário. Temos notícia que eram já apresentadas "peças" em Atenas desde 558 a.C., associadas a Téspis, o primeiro autor de que temos notícias. ${ }^{14}$ Mas foi Pisístrato quem determinou que fossem encenadas em uma das festas mais populares, justamente as Grandes Dionísias Urbanas, em fins de março. Pisístrato com isso estava fazendo uso da religião contra a aristocracia, reorganizando as festas tradicionais e especialmente dando patrocínio estatal ao culto mais popular no momento, o de Dioniso e de sua festa mais importante, as Dionísias Urbanas.

Segundo os poucos dados que temos, a primeira representação de uma tragédia dentro das Dionísias Urbanas foi aproximadamente entre 536 e 533 a.C. p. 26.

12 Nos períodos de 561-555 a.C., 544-538 a.C. e 534-533 a.C. cf. HARVEY, p. 384.

13 AMOURETTI; ROUZÉ, op. cit., p. 254.

14 HAIGH, A. E. The tragic drama of the greeks. New York: Dover Publications, 1968. 
Temos poucos dados também sobre os autores dessa primeira fase do teatro grego. Após Téspis temos notícia de Quérilo, que teria composto aproximadamente 160 tragédias, e de Frínico, discípulo de Téspis, cuja primeira vitória se deu entre 511 e 508 a.C. Mas os grandes nomes da tragédia grega se situam no século $\mathrm{V}$ a.C. e são sem dúvida Ésquilo, Sófocles e Eurípides. Infelizmente chegaram até nós apenas cerca de $10 \%$ de sua produção total. Sete tragédias de Ésquilo, sete de Sófocles e 18 de Eurípides.

Já nas Dionísias Rurais eram reapresentadas para o público do interior da Ática as peças que haviam sido produzidas nas Dionísias Urbanas. A princípio, as peças apresentadas nas Dionísias Urbanas não podiam ser reapresentadas em Atenas, mas a partir da morte de Ésquilo em 456 a.C., devido ao seu enorme prestígio, suas peças foram remontadas, provavelmente por seu filho. Alguns autores na verdade consideram que "Prometeu acorrentado" não teria sido de sua autoria, mas sim desse filho, que a teria montado usando o nome prestigioso do pai.

Portanto o teatro trágico grego tem uma dupla ambientação: religiosa, por um lado, já que se insere no calendário festivo-religioso, mas, conjuntamente, política, pois é também uma festa estatal. Cabe à cidade, à polis, se incumbir dos preparativos para a sua realização.

Com o desenvolvimento do gênero teatral, que praticamente tornou-se o gênero literário mais importante na Grécia durante o século V a.C., as Grandes Dionísias atraem um público cada vez maior. É a própria cidade, Atenas, que se reúne em peso para assistir anualmente, em um momento especial do calendário religioso, tragédias e comédias. É portanto para a pólis que as peças serão direcionadas. Mas não só. Aos poucos, estrangeiros também participarão, muitos vindos de outras cidades gregas, alguns vindos mesmo de outros países, exclusivamente para assistir às representações teatrais. $O$ teatro ateniense passa a ser cada vez mais o rosto mais atrativo que a cidade mostra de si mesma, símbolo de sua importância cultural diante de seus vizinhos e, de certa forma, parte da política hegemônica ateniense na área do Mediterrâneo oriental a partir das vitórias contra as invasões persas. ${ }^{15}$

Após a regulamentação instituída por Pisístrato, as Grandes Dionísias ou Dionísias Urbanas passaram a ser um conjunto de manifestações religiosas, políticas e poéticas com uma programação definida. ${ }^{16}$

O festival se estendia por seis dias, dos dias 10 a 15 do mês Elafebolión, o que corresponde em nosso calendário a finais de março e inícios de abril. 
Durante esses dias além das atividades propriamente religiosas aconteciam quatro tipos de apresentações artísticas na forma de concursos: ditirambos, comédia, drama satírico e tragédia. Destas, as três primeiras têm um vínculo claro com Dioniso, já para a tragédia a relação não é tão óbvia.

No primeiro dia do festival, dia 10 , um grande cortejo conduzido pelo arconte-rei e protegido pelos efebos, jovens de 16 a 18 anos, acompanha a estátua de madeira de Dioniso Eleutério, o Libertador, que é trazida para a cidade. À noite essa estátua será levada ao teatro à luz de tochas. Deste cortejo participam todos os concorrentes nas diversas modalidades poéticas. Durante todo este primeiro dia um grande sacrifício de inúmeros animais, uma hecatombe, alimenta animados banquetes por toda a cidade.

Nos dias 11 e 12 temos o concurso de ditirambos, que eram cantados em louvor a Dioniso em coros de homens e crianças. No passado, na realidade ou através de uma simulação, esses coros de origem muito antiga acompanhariam um rito de sacrifício dionisíaco com dilaceração e consumo das carnes da vítima viva e do seu sangue ainda quente.

Na noite do dia 12 para o dia 13 havia um grande kômos, procissão irreverente de foliões com faloforia, isto é, o transporte do falo, na qual apareciam figuras disfarçadas e mascaradas, em geral de sátiros ou de animais. Seu argumento era em geral rudimentar. Havia uma entrada em cena tumultuada, uma discussão por motivo fútil e um discurso-bufo final. $\mathrm{O}$ kômos foi na verdade um espécie de embrião da comédia.

No dia seguinte, havia justamente o concurso de comédias. Nelas temos retomado o argumento simples do kômos em uma forma mais elaborada nas suas três partes principais: párodo, entrada tumultuosa do coro, evocando eventualmente uma cena conhecida, agón, disputa entre as personagens, e parábase, quando o coro dirige-se diretamente ao público, solicitando-o como testemunha. No entanto, a comédia diferenciava-se do kômos primitivo por já não apresentar com tanta freqüência Dioniso e seu cortejo.

Os dias 14 e 15 , os dois últimos dias do festival, eram reservados aos concursos trágicos. Neles, cada autor apresentava três tragédias, a chamada trilogia, e finalizava com um drama satírico, chamado também de drama silênico. Todo o conjunto das 4 peças constituía a tetralogia. A trilogia em seus princípios apresentava unidade temática. Apenas uma trilogia temática chegou até nós, a "Orestia", ou a "Trilogia de Orestes", de Ésquilo. Nela, a primeira tragédia representava o regresso e morte de Agamêmnon nas mãos da esposa, Clitmemnestra; na segunda, seu filho, Orestes, o vinga matando a própria mãe; e na última Orestes é inocentado do matricídio pela intervenção da deusa Atena. Apesar da grandiosidade deste tríptico, a trilogia de mesmo tema praticamente 
não foi mais usada por Sófocles e Eurípides, sendo cada uma das tragédias em cada trilogia uma unidade em si. O elemento mais importante do drama satírico, e que lhe dava nome, era o coro de sátiros que representava sob a forma de danças acrobáticas o aspecto exterior da manía, a loucura decorrente da possessão divina. Esses dramas satíricos eram algo semelhantes às tragédias na forma, mas aproveitavam os detalhes grotescos das lendas antigas no seu conteúdo. Uma das nossas mais importantes lacunas em relação ao teatro grego deve-se ao fato de apenas um drama satírico ter chegado completo até nós pela tradição, os "Ciclopes" de Eurípides, além de um fragmento extenso dos "Icneutas" de Sófocles.

É interessante essa composição de tragédias e drama satírico em uma unidade maior, da qual em geral temos apenas a porção trágica. Muitos autores associam a tragédia ao sacrifício de um animal. Como vimos, nas Grandes Dionísias era sacrificado um bode a Dioniso e bode em grego é trágos. Em geral a morte de animais na caça ou em sacrifícios estava associada a sentimentos de culpa pelo sangue derramado que em tudo é igual ao do próprio caçador ou sacrificador. $\mathrm{O}$ animal abatido precisa ser apaziguado de certa forma para que não perturbe o seu matador. Em geral uma série de rituais ou atitudes tem essa função. Pois bem, se a trilogia trágica é o momento do sacrifício, do derramamento de sangue, da matança, deve haver alguma compensação em cena. Burkert $^{17}$, portanto, considera natural que às tragédias sucedesse um drama satírico, pois os bodes seriam trazidos de novo ao palco, agora vivos, na verdade transbordantes de vida e energia, revertendo os maus fluidos através da ressurreição e assim fechando um ciclo. Já do ponto de vista do espectador, depois de uma sequiência de três tragédias, há uma grande quantidade de tensão naturalmente acumulada e que teria seu momento de liberação através do drama satírico.

Seria importante que enfatizássemos o caráter competitivo das representações teatrais. Esse caráter, na verdade, como sabemos desde Nietzsche, é uma das forças motrizes da cultura grega. Como diz Burkert ${ }^{18}$, "é surpreendente a quantidade de coisas que entre os gregos se podem tornar objeto de competição: esporte e beleza corporal, artesanato e arte, canto e dança, teatro e disputa." O enfrentamento, a competição pública (agón), parece atrair irresistivelmente os gregos e todas as suas festas apresentam algum tipo de competição. Não devemos nos esquecer que a civilização grega tem um caráter fortemente público. Desde os poemas homéricos, os heróis têm o seu status definido pelos feitos que realizam publicamente, diante de iguais. Os Jogos Olímpicos, cujo

17 BURKERT, op. cit., p. 374.

18 lbid., p. 234. 
primeiro registro é de 776 a.C., são o exemplo máximo dessa compulsão competitiva em festivais religiosos, neste caso, em homenagem a Zeus e de caráter pan-helênico, nos quais não só atletas de várias cidades gregas competiam nas diversas provas, mas também poetas e oradores.

O espírito agonal também marcará a tragédia grega, não só pelo fato exterior da competição entre os próprios tragediógrafos, mas incorporado como uma de suas partes mais essenciais, a cena de enfrentamento. Assim, é importante sabermos que os autores apresentam suas peças desejando muito vencer $\mathrm{e}$ isso acabava por estabelecer um forte vínculo entre o criador e o público para $o$ qual ele cria.

Esse público é em geral amplo, pois todos participam, estrangeiros, metecos, isto é, estrangeiros residentes em Atenas, mulheres e talvez mesmo escravos. ${ }^{19}$ Os espetáculos se sucediam ininterruptamente da manhã até o meio da tarde. A luz solar é um elemento constitutivo do teatro grego que nossas encenações modernas em geral não apresentam, constrangidas pelo palco italiano. $\mathrm{O}$ ambiente durante a encenação provavelmente era o de qualquer festival, com agitação e tumulto devido ao público muito grande, e provavelmente havia consumo de comida devido à longa duração. O que nos faz lembrar um pouco o tipo de público que Shakespeare teve em suas peças.

Esse enorme público era devido ao grande acontecimento que eram as representações teatrais. Em primeiro lugar era a grande festa de Dioniso, que por si só era motivo de atração, e além disso havia o caráter único de cada apresentação, que durante muito tempo não voltaria a ser exibida, a curiosidade geral para saber como seria tratado um tema já conhecido por todos, e o simples prazer das pessoas que se reúnem para uma atividade em comum.

É nesse ambiente de festa religiosa, festa do espírito e da coletividade, que as tragédias eram apresentadas e por isso tiveram um grande papel na formação de espírito "nacional" de Atenas.

Mas como dissemos, a sua organização e funcionamento cabia à cidade dentro do ano religioso. Especificamente a responsabilidade da organização era do arconte-epônimo. A comunidade ateniense mantinha ainda uma antiga divisão em tribos. A partir do regime democrático, das antigas quatro tribos tradicionais foram formadas dez novas. De cada tribo era escolhido um arconte,

19 Existem dúvidas ainda sobre a constituição do público teatral na Atenas no século $\mathrm{V}$ a.C. Alguns autores defenderam mesmo que as mulheres não teriam lugar na platéia. Particularmente nāo concordamos com essa posição, pois muitas falas trágicas importantes não teriam sentido se não fossem dirigidas a uma parcela feminina do público. Este é o caso, por exemplo, da célebre fala de Medéia sobre a condição feminina: "De todos os que têm vida e têm noção,/nós, mulheres, somos o ser mais infeliz". In: EURÍPIDES. Medéia. Trad. de Jaa Torrano. São Paulo: Hucitec, 1991, p. 230-231. 
que era uma espécie de ministro. Esses 10 arcontes organizavam durante um ano o conjunto da vida cotidiana e religiosa na cidade de Atenas. Um deles chamavase arconte-rei, ou também arconte-epônimo, pois dava seu nome ao ano em curso. Era o arconte-epônimo que tinha a função de escolher três poetas trágicos dentre os autorizados a concorrer nos concursos.

Os elementos fundamentais do drama grego, seja tragédia ou comédia, são o coro e os atores. O coro era em geral constituído por 12 ou 15 pessoas que cantavam e dançavam. Os atores eram em número máximo de três. Tanto os participantes do coro como os atores eram sempre do sexo masculino. Mais adiante nos deteremos mais detalhadamente no coro e nos atores.

Era do arconte-epônimo também a escolha de um cidadão rico disposto a assumir o pagamento de um imposto voluntário para financiar os custos da produção de todas as peças. Esse homem chamava-se corego e sua função era a coregia.

Os custos basicamente eram o orçamento do coro mais o tocador de aulos, e das máscaras e trajes para o coro. Era responsável também pelo pagamento do salário do corifeu e dos atores, que são já semiprofissionais. $\mathrm{O}$ ator mais importante, o protagonista, era pago pela cidade.

A coregia podia ser recusada, mas dava prestígio social, e muitos dos principais agentes políticos de Atenas, como Péricles, a assumiram. ${ }^{20}$

O trabalho do autor uma vez composta a peça e a música seria basicamente de trabalhar como ensaiador do coro e dos atores durante os ensaios. Os autores trágicos do século V a.C., muito especialmente Frínico e Ésquilo começaram suas carreiras como atores e atuaram em suas próprias peças.

A princípio as peças eram representadas na Ágora, onde eram montadas arquibancadas de madeira. Este lugar era a praça e mercado públicos da cidade. Lá, ao ar livre, os camponeses vendiam seus produtos, os peixeiros e os padeiros tinham seus tabuleiros e os banqueiros e cambistas tinham suas mesas. A Ágora era o lugar por excelência para encontros e conversas em geral. A partir da instauração do regime democrático em Atenas (508 a.C.), passou também a ser o local de encontro da Ecclesía, a Assembléia dos Cidadãos, principal órgão legislativo da cidade. Esta convivência em um mesmo local das apresentações teatrais e das deliberações políticas durou pouco tempo. Um grave acidente em que se feriram espectadores no desabamento das arquibancadas provisórias teria sido o motivo para a mudança de local. No início do século $\mathrm{V}$ a.C. os concursos teatrais se transferem para a Acrópole, a parte alta da cidade, onde se concentravam os principais templos. Na encosta suleste da Acrópole ficava o santuário de Dioniso e ali foi construído o novo teatro, o Teatro de Dioniso. No início, os

20 "Os persas" de Ésquilo, significativamente, teve a coregia de Péricles. 
assentos para os espectadores foram toscamente escavados na própria colina. Já os lugares de honra eram de pedra e reservados a magistrados e aos sacerdotes de Dioniso. Somente ao final da obra, em aproximadamente 330 a.C., o teatro assumiu a forma que conhecemos, já todo em pedra. Sua capacidade total para alguns seria entre 14.000 e 18.000 espectadores, para outros, chegaria aos 27.000. Justamente por isso era usado não somente para representações dramáticas mas também para cerimônias de várias espécies e até para reuniões da Assembléia dos Cidadãos, retomando a comunidade espacial dessas duas importantes instituições atenienses que já tinha ocorrido no século anterior. $\mathrm{Na}$ verdade, esta relação vai bem além de um simples compartilhamento de um local. Se no teatro as peças, direta ou indiretamente, falavam das questões políticas que envolviam a cidade, na assembléia, que se reunia no anfiteatro na Pnix, a 600 metros da Acrópole e com capacidade para aproximadamente 20.000 cidadãos, os oradores, da tribuna, usavam de todos os recursos retóricos e teatrais no convencimento em favor de suas teses. Assim a Assembléia era um outro palco na cidade e o Teatro um outro lugar da política.

No final das representações, os jurados, que eram designados por sorteio (lembremos que o sorteio para os gregos é uma forma da manifestação da vontade divina) atribuem o prêmio ao poeta vitorioso e ao melhor corego. Os atores tinham prêmios especiais. Os vitoriosos tinham seus nomes gravados em pedra. $^{21}$ Ésquilo venceu 14 vezes, Sófocles, 24 , sendo que nunca tirou um terceiro lugar. Eurípides, que teve maiores problemas de aceitação devido a seus temas mais polêmicos, apenas cinco, sendo que "Medéia" tirou um humilhante terceiro lugar.

Embora os prêmios aos vencedores fossem de um valor considerável, autores e atores não viviam totalmente do teatro. Todos tinham seus próprios negócios, além de eventualmente exercerem cargos públicos como exigia a democracia ateniense. Somente muito mais tarde, no periodo helenístico, os atores se reuniram em uma associação verdadeiramente profissional, chamada de "Artistas de Dioniso", e foram também usados como correios diplomáticos.

Para termos uma idéia do caráter nacional do empreendimento teatral, depois da festa, no próprio teatro, acontecia uma sessão da Assembléia geral dos cidadãos para a crítica da organização do festival. Era uma festa da cidade para a cidade e também para os visitantes e por isso era importante que tudo saísse bem. Outro indício da importância que era dada ao teatro na festa: a entrada era paga e o dinheiro recolhido era usado na conservação do teatro, mas, sob o regime de Péricles, o estado concedia ao cidadão pobre 2 óbolos, aproximadamente um dia de trabalho, para que pudessem pagar a entrada $e$ ir ao teatro.

21 Essas listas de vencedores chamavam-se didaskaliai. 


\section{O núcleo da tragédia}

Os elementos básicos da tragédia eram:

1) Coro: composto por 12 ou 15 elementos, os coreutas. Após entrarem na orquestra, a área de dança no teatro, cantam e dançam nesse espaço. Estes dançarinos-cantores eram em geral homens jovens que estavam a ponto de entrar para o serviço militar após alguns anos de treinamento. Não eram portanto profissionais do teatro e daí a importância do tragediógrafo também como ensaiador do coro, muito embora os atenienses desde crianças fossem ensinados a cantar e dançar.

O coro trágico quase não participa da ação, limitando-se apenas a comentá-la e expressar compaixão ou outros sentimentos pelas personagens. Algumas vezes também destaca o sentido religioso da ação e a intercala com preces. Por outro lado, simboliza o grupo - cidade ou exército - cuja sorte está ligada às personagens. ${ }^{22}$

Os movimentos do coro possivelmente eram usados também artisticamente pelo tragediógrafo, que era ao mesmo tempo coreógrafo, para mostrar ao público as flutuações de relações de poder e as interações entre os caracteres.

De todos os elementos do teatro grego, o coro é sem dúvida o mais estranho para o público moderno. Foi na verdade o núcleo inicial do teatro grego, embora percebamos que sua função se enfraquece aos poucos durante todo o século $\mathrm{V}$ a.C. e seguinte, na exata medida em que os atores no palco tornam-se cada vez mais o centro da ação. Na evolução do teatro ocidental se transfomará posteriormente em mero interlúdio musical entre os atos e finalmente desaparecerá, sendo ressuscitado modernamente pela ópera e sua filha bastarda, a comédia musical.

2) Corifeu: é um membro destacado do coro que pode cantar sozinho. Em geral tem 3 tipos de funções principais: a) exortar o coro à ação, a começar o canto; b) antecipar, ou resumir, as palavras do coro; c) representar o coro, dialogando com os atores.

3) Atores: representam deuses ou heróis. São em número muito reduzido, comparando-se com o teatro atual. $\mathrm{Na}$ verdade, pode-se dizer que o teatro surge quando Téspis cria a figura do ator e ele passa a dialogar com o coro. Seu número sobe para dois e em seguida três, mantendo-se nesse patamar, mas podemos observar que a estruturação dos diálogos nas tragédias tende a se concentrar em dois atores apenas, sendo raras as cenas que apresentam um verdadeiro diálogo

22 Como exceção existiam coros trágicos muito ativos, como por exemplo o coro das Erínias n'As eumênides de Ésquilo. Cf. ÉSQUILO. Oresteia. Trad. de Manuel de Oliveira Pulquério. Lisboa: Ediçōes 70, 1991. 
a três. É no diálogo entre atores que se concentra quase a totalidade da ação dramática.

Os três atores tinham nomes que revelam uma relação hierárquica: protagonista: primeiro ator 23

deuteragonista: segundo ator

tritagonista: terceiro ator.

Uma questão interessante é o fato de existirem vários personagens infantis nas tragédias sobreviventes. Na verdade não sabemos com certeza se esses personagens eram interpretados por adultos ou crianças, mas uma pesquisadora, Emma Griffiths ${ }^{24}$, da Universidade de Bristol, aponta que os movimentos desses personagens em geral são orientados por deixas de outros atores, exatamente como se o autor estivesse procurando meios para evitar as dificuldades inerentes ao se trabalhar com crianças.

\section{O teatro de Dioniso: as condições da performance}

O théatron, ou seja, o auditório, como vimos, era de grandes proporções, o que significa que os espectadores nas últimas filas ficavam a mais de 65 metros da área de representação, e os mais próximos a 10 metros, em uma época sem óculos ou aparelhos de surdez. A consequêencia cra que o estilo de interpretação utilizado pelos dramaturgos era mais declamatório do que naturalista. Os atores deveriam declamar seus versos mais como oradores, uma vez que sutis nuances de voz provavelmente não seriam perceptíveis pela audiência.

No início havia muito pouco cenário, apenas uma tenda, skéne $e^{25}$, onde os atores trocavam de roupa. $O$ vestuário não parece ter sido de feitio natural. Os atores usavam roupões finamente decorados e botas, como os músicos e os sacerdotes. Usavam também máscaras de algum material leve, estas sim com feições mais naturais e que se ajustavam ao rosto do ator acompanhadas de perucas e com bocas abertas para facilitar a dicção.

É difícil dizer de que material eram feitas as máscaras. Como eram perecíveis, nenhum exemplar chegou até nós e a única informação que temos delas é através das pinturas em vasos. Alguns especialistas defendem que seriam de madeira, como as máscaras no teatro Nô japonês, outros que seriam de couro, 
como na Commedia dell'Arte, e outros finalmente de pedaços de pano e pasta de farinha, como muitas máscaras feitas para o carnaval de Veneza ${ }^{26}$.

Se por um lado as máscaras impediam o uso das expressões faciais por parte do ator, por outro facilitavam a caracterização, pois ajudavam o público a identificar o sexo, idade e nível social da personagem. Temos imagens em vasos de atores estudando suas máscaras para aperfeiçoar a interpretação, que sem dúvida se concentrava mais na voz e nos gestos para expressar as emoções. Alguns autores consideram que estas condições materiais da interpretação teriam uma certa influência na própria estrutura das tragédias, que apresentam cenas curtas e limitadas, em geral, a monólogos e diálogos, uma vez que o público teria dificuldade de perceber quem estaria falando devido às máscaras que impediam a visão do movimento dos lábios. Como resultado, a tragédia grega tenderia a ter um caráter em geral estático e algumas vezes mesmo hierático na sua apresentação. Havia sem dúvida uma ênfase maior na palavra, recitada ou cantada, do que na ação. É difícil para nós imaginarmos atores trágicos tendo algum tipo de movimento mais brusco em cena.

$\mathrm{A}$ indumentária dos atores acima descrita era a dos atores no século $\mathrm{V}$ a.C. e não deve ser confundida com a indumentária do posterior palco romano, com sapatos de plataforma alta e máscaras pesadas com bocas como um megafone. As máscaras eram necessárias não somente para que os atores $\mathrm{e}$ membros do coro pudessem assumir papéis femininos, mas também para permitir que um número reduzido de atores pudesse interpretar múltiplos papéis.

A linguagem utilizada, por sua vez, era a convencionada para o gênero e muito artificial, não variando de personagem para personagem. ${ }^{27}$

Além do théatron, literalmente o "local de ver", havia a orquestra, literalmente, o "lugar de dançar", em forma de grande círculo. Era aí que o coro cantava e dançava e, com raras exceções, permanecia durante quase a totalidade da peça.

No lado oposto, havia a skéne, uma tenda que tinha inicialmente a função de ser um lugar para a troca de roupa dos atores. Era uma estrutura provisória, que depois passou a ser construída em madeira apenas para as encenações. As primeira tragédias, incluindo "Os persas", "Os sete contra Tebas", "As suplicantes" e "Prometeu acorrentado", teriam sido encenadas na orquestra com atores e coro no mesmo nível. Aos poucos a skéne foi se incorporando às peças, e sua fachada, provavelmente pintada, usada como cenário, mas talvez não antes de

26 Cf. Didaskalia home page.

27 Se esta descrição da tragédia grega nos faz lembrar mais a ópera que nosso moderno eatro naturalista, isso não é por acaso. $\mathrm{Na}$ verdade a ópera surgiu como uma tentativa consciente de reviver $o$ antigo teatro grego. 
460 a.C. Tinha apenas uma porta central, embora alguns autores proponham três, e um telhado horizontal, onde personagens podiam aparecer, especialmente deuses. Em geral as cenas transcorriam em frente a palácios, templos etc., sem cenas interiores, como costumamos ver no teatro moderno. E isso não deixava de ser natural para os espectadores daquela cultura, uma vez que estavam acostumados a tratar seus negócios públicos, civis ou religiosos, em ambiente externo, ao ar livre.

Havia, de cada lado do palco, rampas conduzindo à orquestra chamadas eísodos. Os atores podiam descer e se juntar ao coro na orquestra, mas o coro não poderia subir ao palco.

Outros acessórios teatrais eram um altar que poderia situar-se no palco ou na orquestra e uma grande plataforma baixa com rodas, o enkíklema, que ao ser rolado para fora através da porta permitiria mostrar cenas interiores que não seriam visíveis da platéia, por exemplo, no caso de ser necessário mostrar-se os corpos de pessoas mortas no interior da skéne.

Mais tarde havia também uma grua ou guindaste, a mechané, que era usada para elevar personagens em vôo, deuses ou heróis, como Belerofonte em seu cavalo Pégaso. Sua utilização mais antiga teria sido em 431 a.C. quando Eurípides o empregou no final da tragédia Medéia. Seu uso se tornou uma prática muito comum no século IV a.C. como um efeito especial que permitia um miraculoso e quase inacreditável final feliz ao trazer nela um deus para dar a solução a uma trama complicada. ${ }^{28}$

As comédias de Aristófanes freqüentemente fazem graça dessa parafernália trágica, mas seu uso era aceito como mais uma das várias convenções do teatro grego.

Esse conjunto de coro e atores, recitando, cantando e dançando, em um teatro com milhares de pessoas, cidadãos e estrangeiros, à luz do dia e dentro de um grande festival estatal em honra a Dioniso que durava 6 dias, infelizmente para nós está completamente perdido. Mas a beleza e profundidade dos textos que chegaram até nós já nos dão uma idéia do que essas representações teriam provocado em seus privilegiados espectadores.

28 A cxpressão latina deus ex machina refere-se exatamente a esta prática teatral e a esse mecanismo. 


\section{RESUMO}

Este artigo é um levantamento geral das condições materiais e históricas do teatro ateniense, i.e., suas origens, organização, performance e formas, tentando enfatizar sua inimitável singularidade.

Palavras-chave: tragédia, teatro, encenação.

\section{ABSTRACT}

This article is a survey of the material and historical conditions of Athenian theater, i.e., its origins, organization, performance and forms, triying to stress its inimitable uniqueness.

Key words: tragedy, theater, performance.

\section{REFERÊNCIAS BIBLIOGRÁFICAS}

AMOURETTI, M.-C; RUZÉ, F. O mundo grego antigo. Lisboa: Dom Quixote, 1993. BURKERT, W. Religião grega na época clássica e arcaica. Lisboa: Fundação Calouste Gulbenkian, 1993.

ELIADE, M. História das crenças e das idéias religiosas, Tomo I, v. 1-2. Rio de Janeiro: J. Zahar, 1978.

EURÍPIDES, Medéia, Trad. de Jaa Torrano. São Paulo: Hucitec, 1991.

ÉSQUILO. Oresteia, Trad. de Manuel de Oliveira Pulquério. Lisboa: Edições 70, 1991. HAIGH, A. E. The tragic drama of the greeks. New York: Dover Publications, 1968. HARVEY, P. Dicionário Oxford de literatura clássica. Rio de Janeiro: J. Zahar, 1987. HOMĖRE. Iliade. Paris: Les Belles Lettres, 1936. 


\section{Sites na Internet}

\section{Didaskalia}

URL: www.warwick.ac.uk/didaskalia/stagecraft/greek.html

Theatre History in Europe: Architectural and Textual Resources Online

URL: www.warwick.ac.uk/fac/arts/Theatre-S/THEATRON

Perseus Project

URL: medusa.perseus.tufts.edu 